\title{
SSynthesis
}

International Scientific Conference of IT and Business-Related Research

\section{MARKET RESEARCH FOR CREATING CURRENT ACCOUNT BALANCE EQUILIBRIUM}

\author{
ISTRAŽIVANJE TRŽIŠTA U FUNKCIJI USPOSTAVLJANJA RAVNOTEŽE \\ BILANSA TEKUĆEG RAČUNA
}

\author{
Ninela Kordić, Jelena Gajić, Jelena Stanković \\ Singidunum University, 32 Danijelova St., Belgrade, Serbia
}

\begin{abstract}
:
The long-term balance of payments and current account balance could be achieved by adequate development policy and rational use of production resources. In order to improve the domestic production and export competitiveness, it is necessary to include marketing activities when creating new investment programs, by using the opportunities and reducing weeknesses that affect economic development. Market research precedes the planning process and foreign trade business activities. Also, market research provides an insight into the needs and possibilities in the market, with the aim of establishing export-import equilibrium. When creating export business plan, it is of vital importance to be competitive in terms of pricing, quality, distribution channels, payment modes and promotion of goods and services. According to these requests, it is necessary to carry on with the organized and continuous market research, which is crucial for defining marketing strategies to be used in export stimulation and enhancement.
\end{abstract}

\section{Key words:}

current account balance, equilibrium, market research, export, goods, services.

\section{INTRODUCTION}

Current account is calculated by adding up the four components of current account: goods (balance of trade), services (intangible trade), income (returns received on factors of production: rent is return on land, wages on labor, interest on capital, profit on enterprise) and current transfers (current transfers include workers' remittances, donations, tax payments, foreign aid and grants).

As a rule, current account is not equable during a single year, it is active or passive. Current account surplus increases a country's net foreign assets by the comparable amount, and a current account deficit does the reversal. This can only happen if some other economies are lending their savings to it (in the form of debt to or direct/portfolio investment in the economy) or the economy is running down its foreign assets such as official foreign currency reserve. There are two kinds of current account disequilibrium - short term (depending on conjuncture) and long term (depending on development).

Balance of payment, as well as current account equilibrium, could be established only by well ordered development policy and economic subjects guidance in obtaining development disequilibrium rejection. It is possible to be done by better organization and rational use of production resources. It is neces-

\section{Apstrakt:}

Dugoročni platni bilans i bilans tekućeg računa može se postići primenom adekvatne politike razvoja i racionalne upotrebe proizvodnih resursa. U cilju poboljšanja domaće proizvodnje i izvozne konkurentnosti, neophodno je uključiti marketinške aktivnosti prilikom kreiranja novih investicionih programa, korišćenjem prilika a smanjivanjem slabosti koje utiču na ekonomski razvoj. Istraživanje tržišta prethodi planiranju i spoljnotrgovinskim aktivnostima. Takođe, istraživanje tržišta daje uvid u potrebe i mogućnosti na tržištu, u cilju uspostavljanja ravnoteže između uvoza i izvoza. Prilikom kreiranja poslovnog plana izvoza, veoma je važno obratiti pažnju na konkurentnost kada je reč o ceni, kvalitetu, kanalima distribucije, načinu plaćanja i promocije robe i usluga. U skladu sa ovim zahtevima, neophodno je da se nastavi sa organizovanim i kontinuiranim istraživanjem tržišta, jer ono ima presudnu ulogu prilikom definisanja marketinških strategija koje se koriste za podsticanje i unapređenje izvoza.

\section{Ključne reči:}

bilans tekućeg računa, ravnoteža, istraživanje tržišta, izvoz, roba, usluge.

sary to bring all forms of consumption within the boundaries of income and provide new investment programs, using the strengths and weaknesses in the overall economic development. The ultimate achievement is to raise the competitiveness of domestic production and exports to foreign markets.

In the opening of development process, countries have to import a lot, especially equipment and raw materials, contrariwise produced goods ends on domestic market for enlarged demand. Consequently, current account deficit came out for enlarged import and decreased export, as well (Kovač, 1994, pp.148-149). After initial period, through right development policy, it is expecting decreasing deficit and crossover into surplus.

\section{EXTERNAL TRADE STATISTICS IN SERBIA}

The assignment and role of external trade statistics comprises establishing general economic policy, trade development policy, including preparation and surveillance of trade agreements, market analysis for exporters and importers, in order to define their commercial strategy, determine strategic goods balances, control agriculture and energy markets, etc. It is important to point out that in the years following the economic sanctions, external trade deficit in Serbia dramatically grew, thus causing 
the breakdown of the economy (Crnomarković, 2010).

The purpose of the export and import statistics is to determine general economic policy, development of trade policy, including the preparation and monitoring of trade agreements, market analysis for exporters and importers, to define their commercial strategy and enable determining the material balance for strategic products, in order to control the market in the field of agriculture, energy, etc.

During the period of 2007-2014, current account deficit was evident. It was the deepest in 2008 (Table 1, Graph 1), amounting to 7.217 million EUR. The main reason for such an extremly high deficit could be found in the growth of private and public consumption and insufficient domestic supply of necessary products.

In 2009, there was a reduction in the deficit (at the level of 2004), due to the impact of global economic crisis. It increased again in 2012, as well as the current account deficit, although the deficit in goods balance was not significantly higher. In 2014, the deficit balance of goods was 4369.2 million. The biggest deficit in trade was with China (imports due to network cell phone and laptop) and the Russian Federation (due to energy imports, mainly oil and gas), followed by the deficit in trade with Germany, Poland (imports of parts for motor vehicles), Hungary, Turkey, Austria and the Netherlands (SORS, Statistical Release, No 26, January 30, 2015).

The structure of exports according to products did not change since 2000, which was taken as the year of the beginning of the transition process in the Serbian economy. Throughout the given period, there is a high proportion of raw materials and semi-finished products (over 50\%) in export structure, the share of consumer goods is decreasing, while the share of the equipment is relatively constant and varies in a proportion of $10 \%$. The structure of export is unfavorable because main export products have little new added value which, consequently, achieve low prices on global markets. Unfortunately, those products exceed half of the total exports (mainly reproduction products and semi-finished products of basic metals).

In the structure of imports, the most interesting data can be found in the area of reproduction products and consumer goods. In the group of consumer goods, non-durable goods are prevailing. The proportion of the equipment is less than $20 \%$ of total imports, and it is insufficient for the country in transition like Serbia. With durable consumer goods, the highest percentage of import can be found in road vehicles and electrical appliances. High percentage import of reproduction goods was the result of several factors. The first reason lies in unrealistic currency rate of the Serbian dinar,which resulted in a situation where some imported products were cheaper than domestic (only those which had its substitute in domestic production). Secondly, considering the principle of classifying products according to its purpose- the predominance, a certain amount of goods was used by the general public.

There are minor changes within country sections involved in external trade. It refers to our second major partner, CEFTA countries, where Serbia gains surplus amounting to USD 1895.5 million, resulting mainly in the export of agricultural products - cereals, followed by various sorts of drinks, as well as export of some finished products.

The external trade in the last year of 2014, as in the years before, noted the highest level, especially with the countries with which Serbia has signed free trade agreements. European Union (EU) countries participated with $63.8 \%$ in the overal Serbian external trade.

One can conclude that the solution for current account balance is to increase exports in the expanding markets, especially export markets such as Asian, African and American countries, or to better use the preferential status of the products in the existing markets. In addition, free trade agreements should be better utilized, which refers in particular to the Russian Federation and Turkey, where opportunities for exporting our prod-

\begin{tabular}{|c|c|c|c|c|c|c|c|c|}
\hline ITEM & 2007 & 2008 & 2009 & 2010 & 2011 & 2012 & 2013 & 2014 \\
\hline Current account & -5.219 & -7.217 & -2.108 & -2.080 & -2.870 & -3.640 & -2.092 & -1.985 \\
\hline Goods & -7.069 & -8.501 & -4.946 & -4.581 & -5.318 & -5.634 & -4.152 & -4.111 \\
\hline Services & -261 & -185 & 21 & 8 & 163 & 139 & 319 & 465 \\
\hline Private remittances & 2.133 & 1.770 & 2.668 & 2.422 & 2.110 & 1.934 & 2.160 & 1.863 \\
\hline
\end{tabular}

Table 1. Section of current account of Serbia/EUR million

Source: According to NBS, Balance of payments, 2007-2011, 2012, 2013, January-December, 2014.

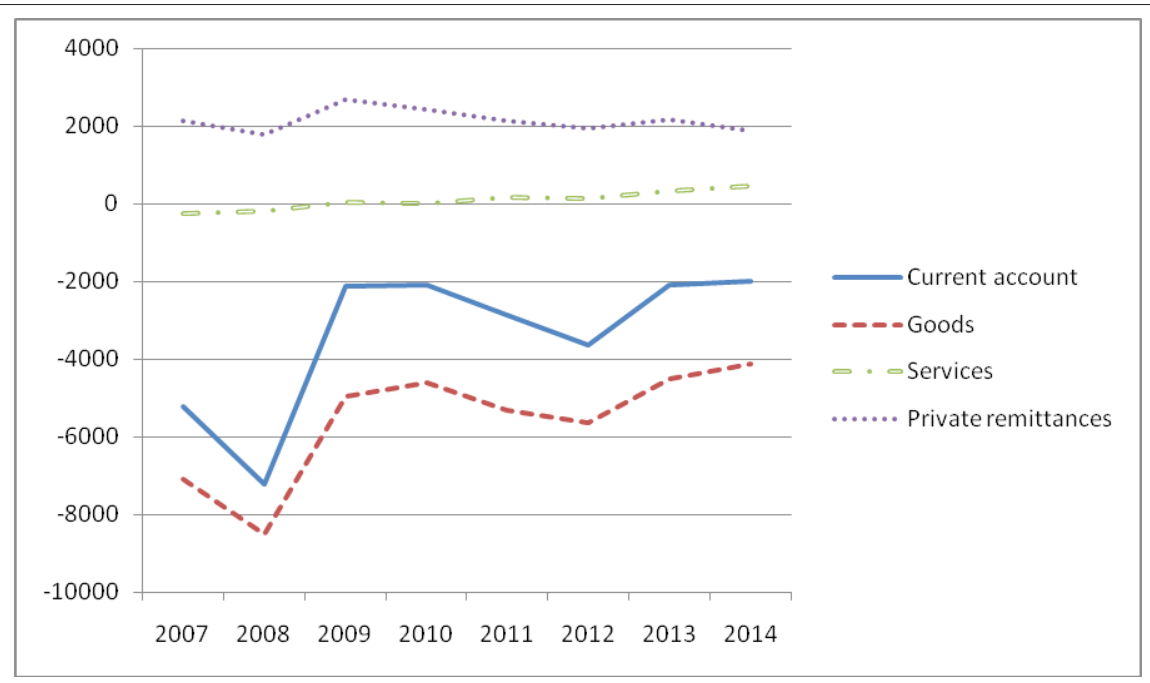

Graph 1. Sections of current account of Serbia/EUR million

Source: According to NBS, Balance of payments, 2007-2011, 2012, 2013, January-December, 2014. 
ucts, especially agricultural are underutilized. China is also a market that should have more importance for Serbian exports in the upcoming years, especially because of the biggest deficit in merchandise trade in 2014 with this country. Exploiting the potentials of new markets requires achieving the appropriate volume of production and making long-term arrangements on delivery of certain goods of great interest.

During the period 2007-2014, the balance of invisible trade (services sector) as part of the current account balance was negative until 2009, when it moved to positive or active and affects a small part in reduction of the goods balance deficit. Data of private remittances suggests that the current account deficit would be greater if there was no such one-way transfer whose role is to reach the level of stability.

\section{CURRENT ACCOUNT DEFICIT SECTION STRUCTURE}

According to the Standard International Trade Classification (SITC), the following items had the greatest deficit in 2014 (table 2, graph 2): the highest deficit was in the sector of mineral fuels, lubricants and related materials amounting to $1.762 \mathrm{mil}-$ lion EUR; the next considerable deficit amount was registered in commodities and transactions not specified in the sector, which amounted to 1.605,7 million EUR (double major to 2013). The latter included: army goods, storage goods with no customs tariff marked,as well as motor vehicle and aircrafts parts. The deficit in the sector of Chemicals and related products,n.e.s. (medicinal and pharmaceutical products, essential oils and resinoids and perfume material, fertilizers, plastics) was $1.364,5$ million EUR.

Stimulating export activities would lead towards establishing better balance between import and export transactions. The first step in encouraging export activities consists of adequate preparation and planning for potential export opportunities (Lovreta, 2008).
It is essential that each company develops a plan of export activity: a description of the company, the characteristics of the market and the industry in which the company operates, description of business objectives and information relating to the products and services, trend analysis and forecasting of future operations, competition and comparison of their advantages and shortcomings, the strategy of international marketing activities, including customer profiling, channels of distribution, employee training and education, as well as financial assessments of the future operations of the company (Team Canada Inc., 2015).

In that sense, it is necessary to conduct deeper and more comprehensive market research, including the analysis of possibilities for the companies, the effects of government subsidies, the risk of possible deterioration of the market situation and the position of the largest among the potential exporters (Jeremic \& Milojevic, 2015, p. 7). The detailed analysis of external trade statistics, associated with market research, should enable collecting necessary data required for making strategic decisions, especially when external trade activities are concerned. Also, when analysing export results, it is necessary to take into account the net export results, because some sectors in the Serbian market are great importers, while others receive government subsidies.

For a successful export, a significant permanent marketing communication market is required. The activities that precede the act of concluding foreign trade business, include monitoring, scanning and analysing marketplace by using contemporary management and marketing techniques, such as propaganda and advertising methods. The export of products needs to be competitive in terms of quality, price, payment methods, so it is recommended for the company to establish and apply Customer Relationship Management concept (Peppers \& Rogers, 2004) to its business (Customer Relationship Management - CRM).

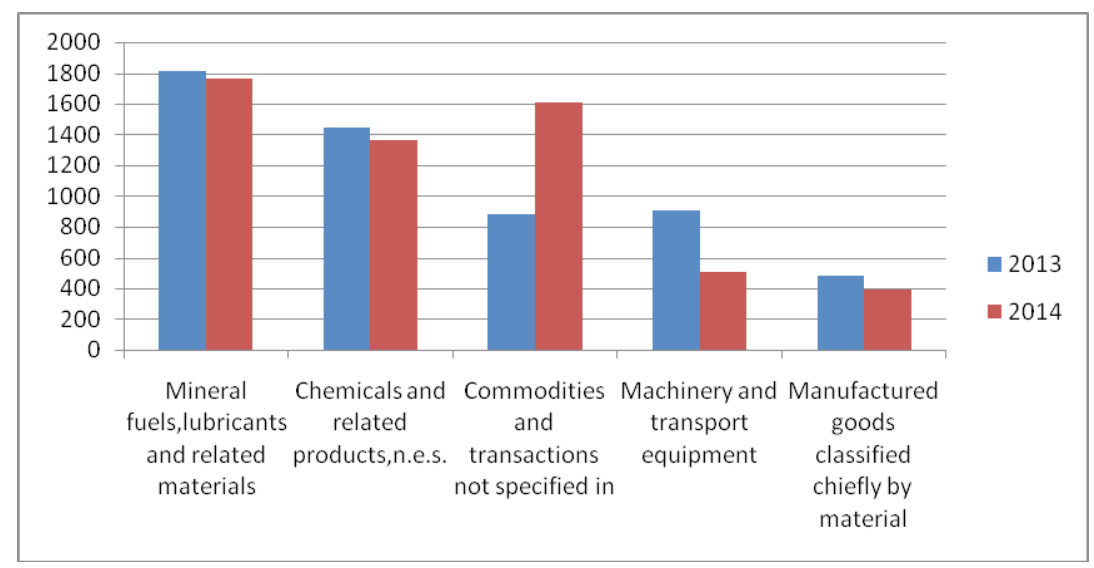

Graph 2. Current account deficit section structure in 2014, Serbia/EUR mill Source: According to SORS, Statistical Release, No 26, January 30, 2015

\begin{tabular}{|l|c|c|c|c|}
\hline \multicolumn{1}{|c|}{ Sector } & \multicolumn{2}{c|}{ deficit } & \multicolumn{2}{c|}{ share \% } \\
\hline & $\mathbf{2 0 1 3}$ & $\mathbf{2 0 1 4}$ & $\mathbf{2 0 1 3}$ & $\mathbf{2 0 1 4}$ \\
\hline Mineral fuels,lubricants and related materials & $1.811,3$ & $1.762,1$ & 15,1 & 14,0 \\
\hline Chemicals and related products,n.e.s. & $1.441,9$ & $1.364,5$ & 15,4 & 14,5 \\
\hline Commodities and transactions not specified elsewere in SITC & 884,6 & $1.605,7$ & 6,3 & 10,9 \\
\hline Machinery and transport equipment & 907,4 & 508,4 & 27,9 & 24,8 \\
\hline Manufactured goods classified chiefly by material & 482,0 & 390,6 & 17,3 & 17,5 \\
\hline
\end{tabular}

Table 2. Current account deficit section structure in 2014, Serbia/EUR mill

Source: SORS, Statistical Release, No 26, January 30, 2015 


\section{EXPORT MARKET ANALYSIS}

In order to define export activities, one should start with the analysis of export markets. The analysis enables collecting relevant data required for making decisions and creating marketing strategies that would effectively support export activities. Such an analysis minimizes the risks of wrong investments and entrances to foreign markets.

Continuous market research (Kotler \& Keller, 2012) provides the basis for estimating potential demand and the amount of supply as necessary conditions for establishing sales plan and budget (Matović, 2014, p. 86) in domestic and foreign markets. On the other hand, market research enables getting a clear insight into economic, demographic, political and techological factors - the so called PEST factors, which significantly effects the companies when planning their sales abroad (Stanković, 2011, pp. 5-6).

The environment of contemporary companies, especially those in production and trade business, is marketing oriented. Marketing concept implies orientation towards establishing long-term company goals in the area of building strong relationships with partners in marketing channels. There are numerous examples of successful use of PEST factor analysis in making business decisions. For instance, the success of exporting self-service retail formats from the USA to European countries during the 1940s, was basically the result of the analysis of environmental factors of that time period (Appel, 1972; Myers \& Alexander, 2007, pp. 6-19). Generally speaking, self-service retail formats, such as Sainsbury's from Great Britain, are based on gaining price competitiveness. The purpose of importing such retail formats to Western European countries after World War II was to serve as a stimulus for the development of those economies.

One of the primary steps when researching export activities is evaluating and ranking the potential markets. The evaluation process comprises assessing the company business policies in terms of entering new markets. The process of defining business policies should include creating product and service offerings, pricing, promotion activities, as well as establishing adequate marketing channels as partner sourcing rather than outsourcing strategies (Stanković, 2009, p. 137).

Creating and defining „4P“ for exporting purposes, should rely on the implementation of IDIC model as support toCRM concept when entering foreign markets. IDIC model comprises four elements (Peppers \& Rogers, 2004, pp. 68-69):

- Identifying customers in foreign markets;

- Differentiating customers and their needs;

- Interacting with customers, in sense of communicating and analysing their needs and characteristics on a regular basis;

- Customizing customer treatment, which actually depends on the capabilities and strategy of the company.

They pointed out that stages or elements of the IDIC model for CRM support should be based on the characteristics of the company, the analysis of the export market, and differentiation strategies as sources of gaining competitive advantage.

At the same time, product and service quality advancement and implementation of innovations and new technologies stimulate the economic growth and contribute to development of economic competency. According to Milisavljević, the results of empirical research show that $50-60 \%$ of the economic growth can be attributed to technological innovations. Also, the position of the companies on the international market is to be assessed by the intensity of technological innovation implemen- tation, as well as by price competency, quality of products and services etc. (Ivanović-Đukić \& Lazić, 2014, p. 52).

\section{EXPORT MARKET RESEARCH PLAN}

Research plan should be defined in accordance with the goals of export or import policy so as to get relevant information for defining export/import strategies. Upon collecting secondary market information, primary export market research should be conducted. As regards potential export markets, necessary information comprises: market size and growth, size and power of competition, barriers to entry into market, economic and political stability, geographical position of the market, culture and customs prevailing in the economy.

Secondary information enables getting insight into trade statistics, industry trends to which the company plans to direct its export and other business activities. In case of Serbian market, the main sources for gathering primary and secondary information, include Serbian Business Registers Agency and Customs Adiministration, as well as the companies which are involved or plan to get involved in export and import activities. On the other hand, there are serious obstacles to gathering valid data for estimating export possibilities and export potentials of the companies. Among others, there is the poor quality of financial reports of the Serbian companies, which usually happens to be the result of the so called "creative accounting " (Jeremic \& Milojević, 2015, p. 7). The characteristic of such non realistic information present in financial reports is that they are based on non-realistic financial estimation and, as such, have a tendency to increase the value of companies' assets. Such so-called „creativity" in displaying financial and other business indicators, represent a serious threat to effective and efficient research process for the companies that intend to export, as well as those dealing with the assessments of export possibilities of enterprises and economies.

Potential unexpected situations in planning export activities cannot be avoided or eliminated. However, one can get prepared on time, and based on research conducted, anticipate future events so as to reduce business risks (Stanković, 2011, p.8). In that sense, it is valuable to keep on analysing business on the following levels of the company (Gilbert, 2003):

a) level of the company as a whole,

b) direct environment of the company level,

c) stakeholder level, and

d) indirect environment of the company level - industry and national market level.

The needs of customers distinguished in domestic and international markets are significantly different, which leads to the necessity of considering the appropriate export strategies. Generally speaking, companies in Serbia can choose between three strategies of internationalisation, depending on their capabilities and assessed market situation(Kotler \& Kelle, 2006, p.675): direct export, indirect export and joint strategic business alliances.

Some research shows that the strategy of direct export should be used only when entering the so called „reasonably accessible markets“. In case of Serbian companies, such markets would be the members of CEFTA. For entering less accessible markets, characterised by different legal and regulatory environment and business practices, customs and preferences, such as the USA market in case of Serbian companies, direct export strategy should not be an option (Team Canada Inc., 2015). In case of entering less accessible markets, cutting in partners from the local market, who are familiar with customs, habits 
and needs of the locals, should be a far better option (Stanković, 2011, p. 125).

According to a group of authors, if Serbia as an economy strives to establish its economic development on the increased export activities, an important condition should be incorporated-advanced information support to potential export markets for all local producers and service businesses (Foundation for the Advancemenet of Economics, 2010).

\section{SUMMARY}

The Serbian economy has manifested a long lasting, structured, current account deficit for over a two -decade period. Current account disequilibrium is due to the value as well as the structure of external trade.

Current account equilibrium could be established only by well ordered development policy and economic subject guidance in obtaining development disequilibrium rejection. In order to achieve this strategic issue, it is necessary to include the preparation and monitoring of trade agreements, market analysis for exporters and importers, defining their commercial strategy and determining the material balance for strategic products. A detailed market analysis of external trade statistics, associated with market research, should enable collecting necessary data required for making strategic decisions.

\section{REFERENCES}

Appel, D. (1972).The supermarket: early development of an instutional innovation. Journal of Retailing, 48(1), 39-53.

Crnomarković, J. (2010). Pregled spoljnotrgovinske robne razmene Republike Srbije u periodu 1988-2009. godine. Retrieved March 01, 2015, from http://webrzs.stat.gov.rs/ WebSite/userFiles/file/Spoljna/Spoljna_092010.pdf (In Serbian).

Foundation for the Advancemenet of Economics. (2010). Postcrisis model of economic growth and development of Serbia 2011-2020. Retrieved February 15, 2015, from www. fren.org.rs.

Gilbert, D. (2003). Retail Marketing Management. Harlow, England: Pearson Education Limited.

Ivanović-Đukić, M., \& Lazić, M. (2014). Incentives to innovation of small and middle sized companies in Serbia in function of competency advancement in the post-crisis period. Economy Themes, 52(1), 49-62.

Jeremić, Z., \& Milojević, M. (2015) The most successful exports and the greatest imports in the period of 2008-2014. The Economy and Finance Board 2015. Belgrade: Serbian Busi- ness Registers Agency, pp. 6-37.

Kotler, P., \& Keller, K.L. (2012). Marketing Management. 14th Edition. Harlow, England: Pearson Education Limited.

Kotler, P., \& Keller, K.L. (2006) Marketing Manadžment. Beograd: Data Status. (In Serbian).

Kovač, O. (1992). Platni bilans i međunarodne finansije. Beograd: CESMECON. (In Serbian).

Lovreta, S. (2008). Strategija i politika razvoja trgovine Republike Srbije. Retrieved February 15, 2015, from http://www.seda. org.rs/download/strategija_i_politika_razvoja_trgovine.pdf (In Serbian).

Matović, V. (2014). Menadžment prodaje. Beograd: Univerzitet Singidunum. (In Serbian).

Myers, H., \& Alexander, N., (2007). The role of retail internationalisation in the establishment of a European retail structure. International Journal of Retail and Distribution Management, 35(1), 6-19.

Narodna Banka Srbije. (2011). Platni bilans Republike Srbije 2007-2011 (BPM5). Retrieved March 01, 2015, from http:// www.nbs.rs/internet/latinica/80/platni_bilans.html (In Serbian).

Narodna Banka Srbije. (2012). Platni bilans Republike Srbije 2012 (BPM6). Retrieved March 01, 2015, from http://www.nbs. rs/internet/latinica/80/platni_bilans.html (In Serbian).

Narodna Banka Srbije. (2013). Platni bilans Republike Srbije 2013 (BPM6). Retrieved March 01, 2015, from http://www.nbs. rs/internet/latinica/80/platni_bilans.html (In Serbian).

Narodna Banka Srbije. (2014). Platni bilans Republike Srbije 2014 (BPM6). Retrieved March 01, 2015, from http://www.nbs. rs/internet/latinica/80/platni_bilans.html (In Serbian).

Peppers, D., \& Rogers, M. (2004). Managing Customer Relationships. Hoboken NJ: John Wiley \& Sons.

Stanković, J. (2009). Managing Change of Customer Relationships In Retail Business. PhD Thesis, University of Belgrade, Faculty of Economics.

Stanković, J. (2011). Trgovina i drugi kanali marketinga. Beograd: Univerzitet Singidunum. (In Serbian).

Statistical Office of the Republic of Serbia. (2015). Statistical Release, No. 26, January 30, 2015.

Statistical Office of the Republic of Serbia. (2014). External trade, December 2014 - By current exchange rate, EUR-(ST13). Retrieved February 15, 2015 from http://webrzs.stat.gov.rs/ WebSite/public/PublicationView.aspx?pKey=41\&pLevel $=1$ \&pubType $=2 \&$ pubKey $=2816$

Team Canada Inc. (2015). 10 Steps to Successful Exporting. Retrieved March 01, 2015, from http://sbinfocanada.about. com/od/canadaexport/a/10exportsteps.html 